submarine frozen ground. Most submarine permafrost probably formed subaerially during full-glacial low sea levels; that on the Siberian Shelf for example, is thus a relict of past climate and is now slowly thawing. Gas hydrates, solids in which molecules of gas are combined with water, are also dealt with, and the links between their stability and considerations of temperature and pressure are outlined.

In summary, books on periglacial environments and permafrost have been consistently strong in their emphasis on geomorphological topics, but rather less concerned with the physical properties, thermodynamics and rheology of frozen ground. The Frozen Earth, therefore, fills a considerable gap in the literature, and will be of importance to both academic and applied workers in the periglacial zone. It is the most significant contribution in this field for a number of years. (Julian Dowdeswell, Scott Polar Research Institute, University of Cambridge, Lensfield Road, Cambridge CB2 1ER, UK.)

\section{THE HEROIC AGE}

SAFE RETURN DOUBTFUL: THE HEROIC AGE OF POLAR EXPLORATION. Maxtone-Graham, John. 1988. Wellingborough, Patrick Stephens. 364 p, illustrated, hard cover. ISBN 1-85260-293-7. £16.95.

The book owes its title to an advertisement reputedly placed in The Times in early 1907 by Ernest Shackleton: 'Men wanted for hazardous journey. Low wages, bitter cold, long hours of complete darkness. Safe return doubtful, honour and recognition in the event of success'. Research over the years has failed to authenticate it, but its context neatly encapsulates the spirit and intent of this enjoyable and well-researched narrative.

Mr Maxtone-Graham has given us not just another popular polar history - he tells us little concerning geographical or scientific discoveries - but rather an imaginative insight into the human side of the heroic epoch. An acknowledged expert in maritime history, and one who writes with panache and con brio, he is well equipped for the task. In 14 chapters, the first of which is appropriately devoted to 'The Britannic example', the author traces the course of polar exploration through the 19th and into the first decade of the 20th centuries, highlighting the two main themes - the achievement of the Northwest Passage and subsequently the race for the North and South Poles. Tales of 'derring do' and high adventure are the order of the day, with the traits and idiosyncrasies of the heroes themselves given due prominence.

What gives this book its particular relish and interest is the author's very evident knowledge of the practical aspects of polar exploration - the problems of ice navigation, the evolution of sledging techniques and the use of dogs, polar rations, and the besetting problems of scurvy which defied solution until after Scott's day. Refreshing also is the lack of acrimony and partisan bias. It is especially welcome to find both Scott and Amundsen viewed in balanced perspective, and sympathetic under- standing is shown for Sir Clements Markham, whose life, which embraced almost the entire 'heroic epoch', clearly intrigues the author. It is disappointing to find no mention of William Scoresby, true father of polar exploration and science (not perhaps a hero?), and the single map is inadequate for following the course of events. (H. G. R. King, Scott Polar Research Institute, University of Cambridge, Lensfield Road, Cambridge CB2 1ER UK.)

\section{ALASKAN ESKIMO MASKS}

AGAYUT: ESKIMO MASKS FROM THE 5th THULE EXPEDITION: KNUD RASMUSSENS SAMLINGER FRA NUNIVAK, ALASKA. Sonne, Birgitte. 1988. Copenhagen, Gyldendal. 375 p, drawings, photographs, soft cover. ISBN 87-00-32832-4. DKr 400.00.

Knud Rasmussen never visited Nunivak Island. This book arises from his chance encounter with a group of Nunivakers in Nome on 31 August 1924, at the end of his threeyear long Fifth Thule Expedition (see profile of Rasmussen, this issue). In Across Arctic America he remarks 'I had reached Nome at a fortunate time for my work. Here were assembled Eskimos from all parts of Alaska ...'. Most had come from many distant villages to sell curios to the tourists, and among them were the group from Nunivak island. With the help of Alaskan trader Paul Ivanoff as interpreter, he made the most of his meeting. On Rasmussen's request, six of the Nunivakers made detailed pencil drawings of their island culture. They ranged from hunting scenes to artefacts and, in particular, shamans' masks. On the basis of these drawings, Rasmussen then asked several Nunivakers to carve some masks in wood. In all 28 masks were carved; together with the drawings, these have been in the National Museum in Copenhagen since 1925.

This volume presents the entire collection and, I am sure, will be welcomed not only by those interested in northern art, but by anthropologists concerned with ceremonialism and ritual. Birgitte Sonne has edited Rasmussen's notes and provided excellent accompanying text in English and Danish. In1924, masks still played an important part in the ritual, belief and mythology of the Nunivak Islanders. Sonne describes the mask performances still to be found at the time, and places them in their social and religious context. Spirit systems and myth are discussed and a comprehensive picture of Nunivak cosmology is presented, a cosmology already influenced by Christianity, particularly the hierarchy of spirits. Such syncretism is not ignored; Sonne considers possible Orthodox and Catholic influence from the mainland. The text is short and precise, clear and easy to follow. There are one or two minor mistakes in the English translation, but otherwise it cannot be faulted. The photographs are beautiful and the text is very well complemented by the drawings given to Rasmussen. Rasmussen's notes appear at the end of the text. The nice thing about this volume is that it can be seen simply as a catalogue of the museum collection, or as an interpretation of Nunivak religious belief. Either way, it makes available some very exciting 
documentation and presents a beautiful and rare collection. (Mark Nuttall, Scott Polar Research Institute, University of Cambridge, Lensfield Road, Cambridge CB2 IER UK.)

\section{THE SOUTH AMERICAN WAY}

STRATEGY IN THE SOUTHERN OCEANS. A SOUTH AMERICAN VIEW. Virginia GambaStonehouse. 1989. London, Pinter Publications (Studies in Contemporary Maritime Policy and Stategy). $155 \mathrm{p}$, maps, hard cover. ISBN 0-86187-017-4. £32.50.

Virginia Gamba-Stonehouse, an Argentinian, read Latin American Studies and Strategic Studies in the UK, taught Military Strategy to the Argentine War Schools and Joint Chiefs of Staff 1984-87, and has been a visiting professor in the USA and at King's College London. Examining strategies of South American countries in relation to each other and to Antarctica, she stresses their own interests in the south, which are neither widely known nor generally understood outside the sub-continent.

Implications of two important maritime issues are analyzed; Bolivian efforts to obtain an outlet to the Pacific Ocean, and the long-lasting dispute over the South Atlantic islands (including the Falklands/Malvinas Islands) and Antarctica. The latter is an important factor in Argentinian-Brazilian relationships. Brazilian geopoliticians support the 'frontage theory' (defrontação) of Brazilian geographer Therezinha de Castro, which postulates that each South American country facing the Antarctic should own the sector of Antarctic territory facing its unobstructed coastline. Understandably this appeals also in Uruguay, Peru and Ecuador, which would gain Antarctic territory from its implementation, but is vehemently discredited in Chile and Argentina, who would lose large portions of their present claims.

The Falklands/Malvinas conflict of 1982 represented competition with an outside country for influence and control of the South Atlantic and Antarctic Peninsula. Latin American treaties important in this area are the InterAmerican Treaty of Reciprocal Assistance (the Rio Treaty of 1947) and the (1967) Tlatelolco Treaty, which excluded nuclear weapons from Latin America. As the Rio Treaty covers the South American sector of the South Atlantic as far as the South Pole, Argentina, and Chile can reasonably claim that their treaty responsibilities extend into the Antarctic. So can Brazil argue its responsibility under the Treaty to defend a sizeable portion of the South Atlantic and Antarctica.

Other South Atlantic conflicts considered by GambaStonehouse include (1) The struggle for presence and influence in Antarctica, because the South Atlantic controls access to important sections, especially Antarctic Peninsula: (2) The Argentine-Chile Beagle Channel dispute, in which Argentina strongly resists Chilean penetration into the South Atlantic; Vatican mediation secured uneasy peace in 1985: (3) Law of the Sea disputes among littoral states over new Exclusive Economic Zones. The author argues that international relations may return to a system balancing South Atlantic states (Brazil, Argentina, Uruguay and Paraguay) against South Pacific (Chile, Bolivia, Peru and Ecuador).

The book concludes with a consideration of perceived strategic values of the Western South Atlantic. The sea is beginning to represent a new dimension for South America, of high strategic value. This is a highly recommended review, and a good source-book for comparative research in Latin America policies. The maps will be invaluable to lecturers on Latin American relations and Antarctica. (Julie Schmied, Scott Polar Research Institute, University of Cambridge, Lensfield Road, Cambridge CB2 1ER UK.)

\section{THE FALKLANDS WAR}

THE LITTLE PLATOON: DIPLOMACY AND THE FALKLANDS DISPUTE. Charlton, M. 1989. Oxford, Basil Blackwell. 230 p, hard cover. ISBN 0-631-165649. $£ 14.95$.

For his title Michael Charlton drew on Edmund Burke: for the text of this inspired book he interviewed some 40 people - diplomats, civil servants, ministers of state and humbler politicians, service chiefs of staff, international gurus, UN officials and many others - who were closely involved in events leading up to the Falklands war of 1982 and the conflict itself. His recordings were made in 198586 in the UK, Argentina and USA, while memories and alibis were still fresh, and edited down to eight $B B C$ Radio Three programmes. The book uses more of the material, and to excellent effect; the author asked sensible questions, and the answers, whether sensible or not, make a fascinating study of history and legend in the making.

Charlton discloses remarkable facts - for example that the first-ever visit of a British Foreign Secretary to Latin America was made in 1966 - and a deal of muddled thinking among all who were most closely involved in the dispute from the 1960 s onward. Did responsible Britons really doubt Argentina's determination to acquire the islands, or only their willingness to use force? Did responsible Argentinians really expect Mrs Thatcher and the Brits to allow them a successful invasion? Hindsight favours the Americans, whose predictions appear sharpest throughout, and the common-sense view of the British parliament comes over surprisingly strongly. Britain's shambling foreign policies contrast with the professionalism of its armed forces. Admiral Lord Lewin sums it up on the last page: after the invasion "The chiefs of staff, I think, would have been perfectly within their rights to have said, 'I'm sorry, prime minister, this is the war [the politicians] told us we would not have to fight, and there is nothing we can do to help you'". The author's conclusion that : 'Britain fought a war ... for islands it had spent the better part of twenty years suggesting it did not want' is inescapable. So is his dictum that '... political leaders who avoid the difficult choices face harder ones in the end'. This is an excellent book, strongly recommended 